\title{
東日本大震災津波による石巻海岸での海浜地形変化 \\ Morphology Changes on Ishinomaki Coast due to The Great East Japan Tsunami
}

\author{
Nguyen Xuan Dao ${ }^{1}$ ・田中 仁 $^{2} \cdot$ Mohammad Bagus Adityawan ${ }^{3}$ ・有働恵子 ${ }^{4} \cdot$ 真野 明 $^{5}$ \\ Xuan Dao NGUYEN, Hitoshi TANAKA, Mohammad Bagus ADITYAWAN \\ Keiko UDO and Akira MANO
}

\begin{abstract}
Changes in shoreline through process of accretion and erosion can be analyzed by applying historical maps along with aerial photographs to measure differences in past and present shoreline locations. In addition, it might be used for determining the long-term changes of coastal geographic features in the past. However, researches on morphology changes on short-term impact of tsunami have not been widely carried out. Therefore, the present study aims to investigate the extensive short-term changes on morphology due to The Great East Japan Tsunami in 2011 along Ishinomaki Coast using historical maps and pre- and post-aerial photographs together with bathymetric surveyed cross-sectional data.
\end{abstract}

\section{1.はじめに}

一般に，津波は大規模な土砂移動を発生させることが 多い. 地層に残された歴史津波の堆積物は過去の津波の 規模を推定するための有力な情報となり得る。このため, 2004 年インド洋大津波や 2011 年東日本大震災津波の後, 陸上部津波堆積物について多くの調査研究がなされてい る. 一方, 海域に生じた土砂移動・地形変化については, 現地資料がきわめて限られており，風波による海浜変形 などに比べて知見が少ない.

高橋ら（1999）は1960年チリ地震津波により気仙沼湾 において生じた地形変化の再現モデルを提案している. 2004年インド洋大津波を対象とした検討としては，スリ ランカ・キリンダ港での土砂移動について高橋ら（2008） が研究を行っている. また，今次津波については，原口 ら（2012）, 有働ら（2013）がそれぞれ気仙沼湾および 仙台海岸における研究を実施している.

本論文では，東日本大震災の前後での深浅測量データ として石巻海岸における資料を解析し，津波による海浜 変形の特徵, ならびにその後の地形の回復過程について 検討を行った。特に，石巻地方では陸域において大規模 な地盤沈下が発生したことが知られており，海底での地 盤沈下量に関する検討も行った.

\section{2. 現地調查および使用したデータ}

石巻海岸の概要を図-1に示す．同海岸においては西向

\begin{tabular}{llll}
\hline 1 & 学生会員 & M.Sc. & $\begin{array}{l}\text { 東北大学工学研究科博士課程 土木工学 } \\
\text { 専攻 }\end{array}$ \\
2 & フェロー & 工博 & 東北大学工学研究科教授 土木工学専攻 \\
3 & 正会員 & Ph.D & 東北大学工学研究科PD 土木工学専攻 \\
4 & 正会 & 博(工) & 東北大学災害科学国際研究所准教授 \\
5 & フェロー & 工博 & 東北大学災害科学国際研究所教授
\end{tabular}

きの沿岸漂砂が卓越している（望月ら，1990; 井上ら, 2002）.ただし，石巻工業港（現仙台塩釜港石巻港区） における防波堤の建設後, 連続的な漂砂移動が阻害され, 海岸侵食が問題となっている，海岸管理者である宮城県 は1980年から海岸侵食防止のため離岸堤 7 基，突堤 8 基 を設置し，2000年に現在の形で概成している（佐藤ら， 1998)。高橋ら（2005）はこれら海岸構造物による海浜 変形への影響を把握することを目的とし，雲雀野防波堤 から宮戸島までの範囲において経験的固有関数法による 解析を実施し, 海浜変形を引き起こす原因について考察 をおこなっている.

本研究においては，高橋ら（2005）と同様に宮城県に おいて測量がなされた津波来襲前後の深浅デー夕を使用 している。深浅測量は2010年12月および2011年8月に実 施されている，図-2には測線の位置を示しており，沿岸 方向約 $12 \mathrm{~km}$ にわたり平均 $380 \mathrm{~m}$ の不等間隔で測量がなさ れている. 望月ら（1990）によると当海域での地形変化 移動限界水深は $8 \mathrm{~m}$ であり, それを越える深さまでの沖 合まで測量がなされている.

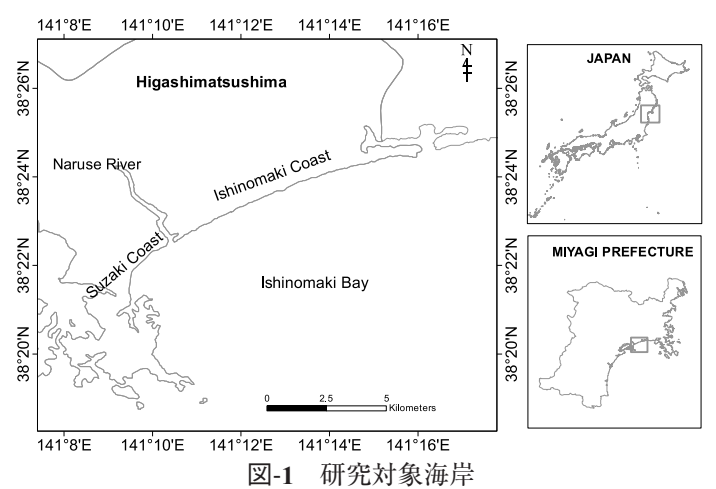




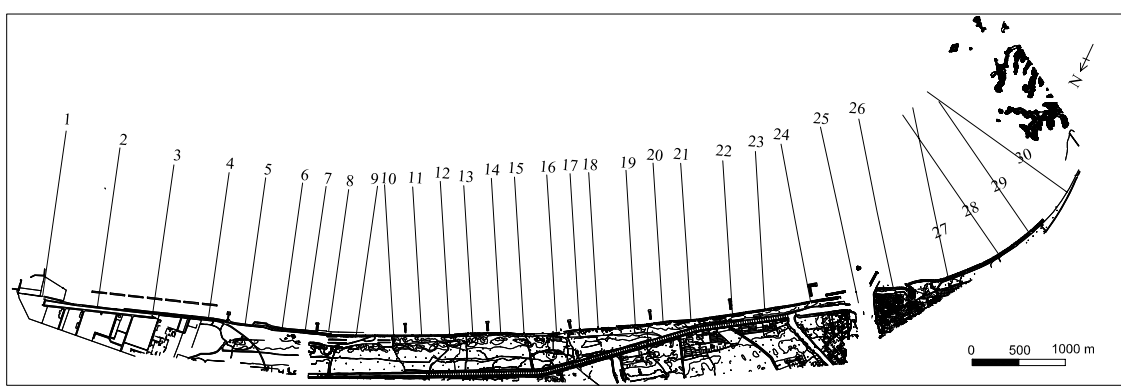

図-2 石巻海岸における深浅測量の測線位置

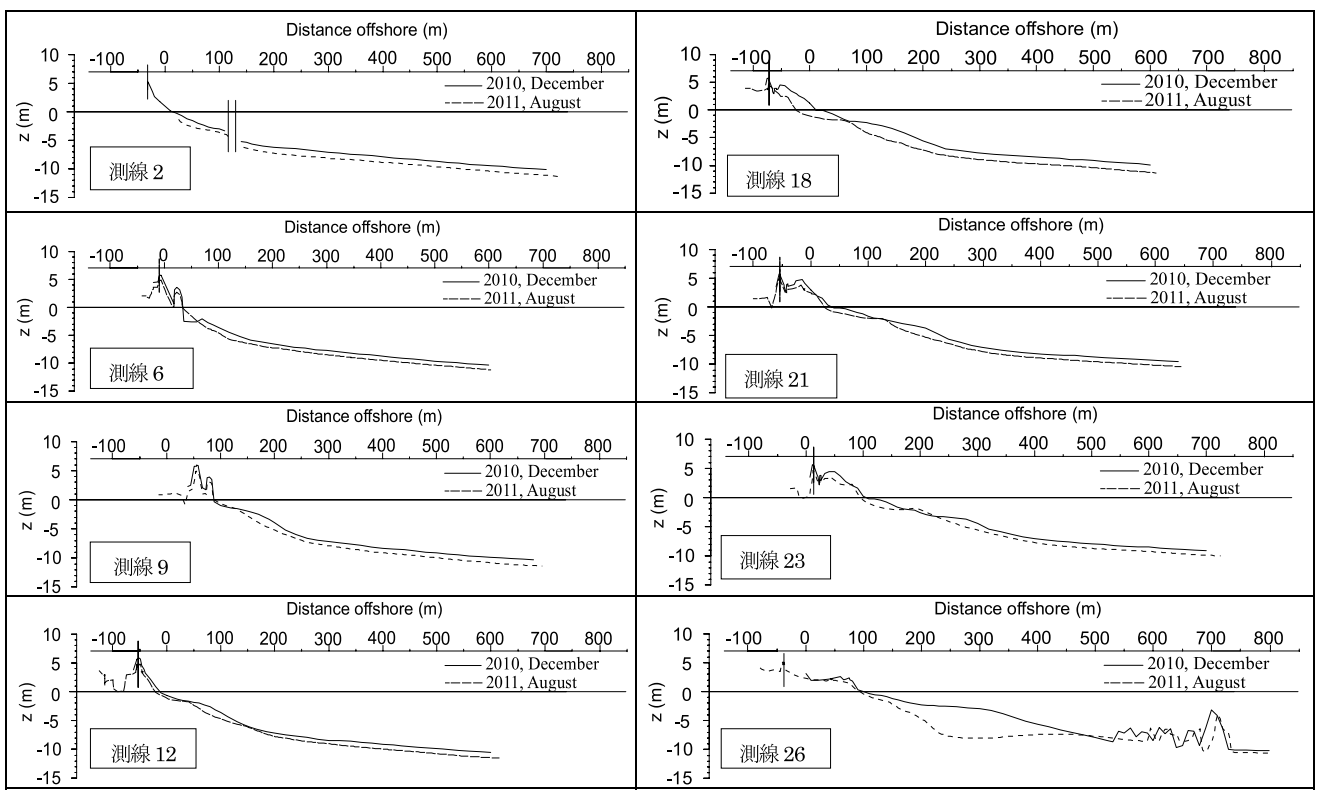

図-3 津波前後での海浜断面の変化

また，過去の汀線変動を調べるために，当地における 海図, 古地図などを収集し, 長期的な地形変化と津波に よる短期的なインパクトの双方を検討した。

\section{3. 結果と考察}

\section{(1) 海浜断面変化の特徴}

図-2に示した全測線のうち, 代表的な海浜断面の変化

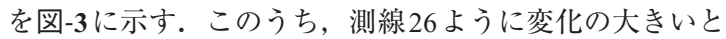
ころも見られるが，ほとんど変化の無い断面が多く見ら れる点に大きな特徴がある。また, 沖の断面がほぼ平行 な形状を保って, 地震後に低下していることが分かる. また、測線 6 ，測線 26 などのように陸上部の海岸堤防や 道路面についても同様に平行移動が認められる。研究対 象に近い石巻市周辺では大きな地盤沈下が生じているこ とが知られており, 図-3に見られる沖側および陸上部で の地盤の平行移動は地盤沈下によるものと推定される.
（2）地盤沈下量の推定

図-4（a）には，測線6における津波前後の測量結果の 比較を $\times$ 印で示す。ここで， $z_{1}, z_{2}$ はそれぞれ津波前後 の測量で得られた砂面の高さ（T.P.）を表しており，一 部は陸上の構造物も含んでいる. 図-4（a）では, 上述の とおり沖合において津波後に $1.20 \mathrm{~m}$ 程度の砂面の平行移 動が見られる。また，陸上部においても同程度の高さの 変化が見られる．この高さ分だけ平行移動を行うと, ○ 印で示された様に沖合および陸上部での高さが一致す る。また，図-4（b）に示された測線23についても同様 な傾向を示しており, 地盤沈下量は $1.22 \mathrm{~m}$ と評価される. このようにして，各測線における海域での地盤沈下量 $\Delta \zeta$ を推定した。

図-5はこの様にして得られた地盤沈下量の沿岸分布で ある. 国土地理院の報告によれば, 石巻市陸上部での地 盤沈下量は最大で $1.2 \mathrm{~m}$ であり，西に向かって漸減し， 図-2の右端付近の東松島市においては $50 \mathrm{~cm}$ 程度であるこ 


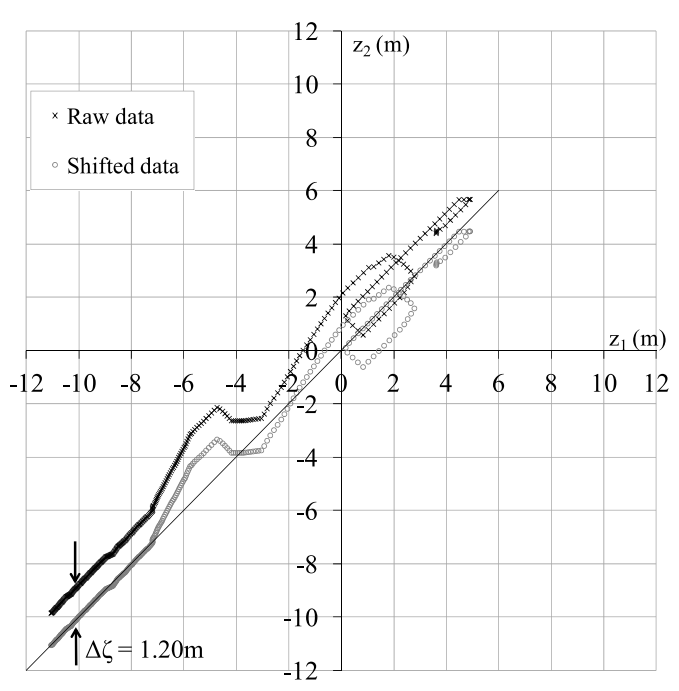

(a) 測線 6

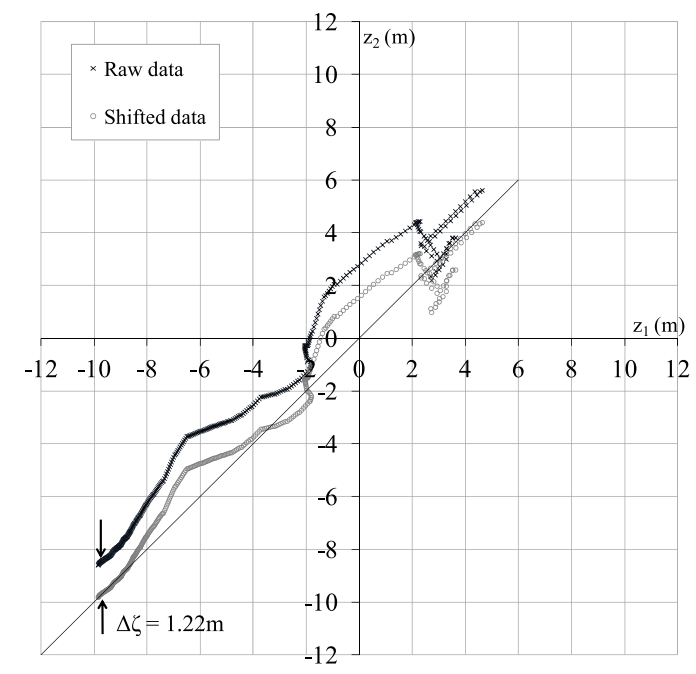

(b) 測線 23

図-4 津波前後での測量結果の比較

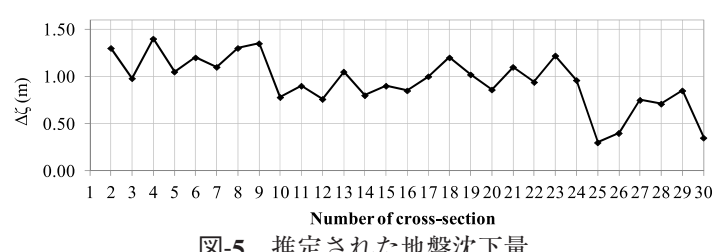

図-5 推定された地盤沈下量

とが知られている（国土地理院，2011）。深浅測量から 得られた図-2上段青線の結果は，このような陸上部地盤 沈下に関する知見ときわめて良好な一致を示している.

以下では, この地盤沈下補正を行った上で, 津波によ る断面変化の検討を行った.

\section{（3）津波による地形変化}

図-6は，津波前後での砂面高さの変化量 $\Delta \mathrm{z}=z_{2}-z_{1}$ を求 め，それぞれの測線について示したものである。このう ち, 測線 $2,3,4 \mathrm{a}$ では横軸の離岸距離が $250 \mathrm{~m}$ の付近に 侵食が見られる。図-2に見られるようにこれらの測線は 離岸堤前面に位置しており，その影響が現れているもの と考えられる。これを除くと, 測線 2 から測線 24 まで目 立った変化は見られない。測線26は鳴瀬川河口前面に位 置しており, 最大で $4.9 \mathrm{~m}$ の高さに及ぶ侵食が見られる. さらに，漂砂下手に向かうと，測線 30 においても顕著な 侵食が見られる。この箇所での侵食については，海岸堤 防の形式の相違による被災の違いが反映されているとの 考察がなされており，その詳細は別報を参照されたい (Nguyen ら, 2013).

次に, 図-7は次式により求めた測線毎の海底面高さ変

$\Delta z(m)$

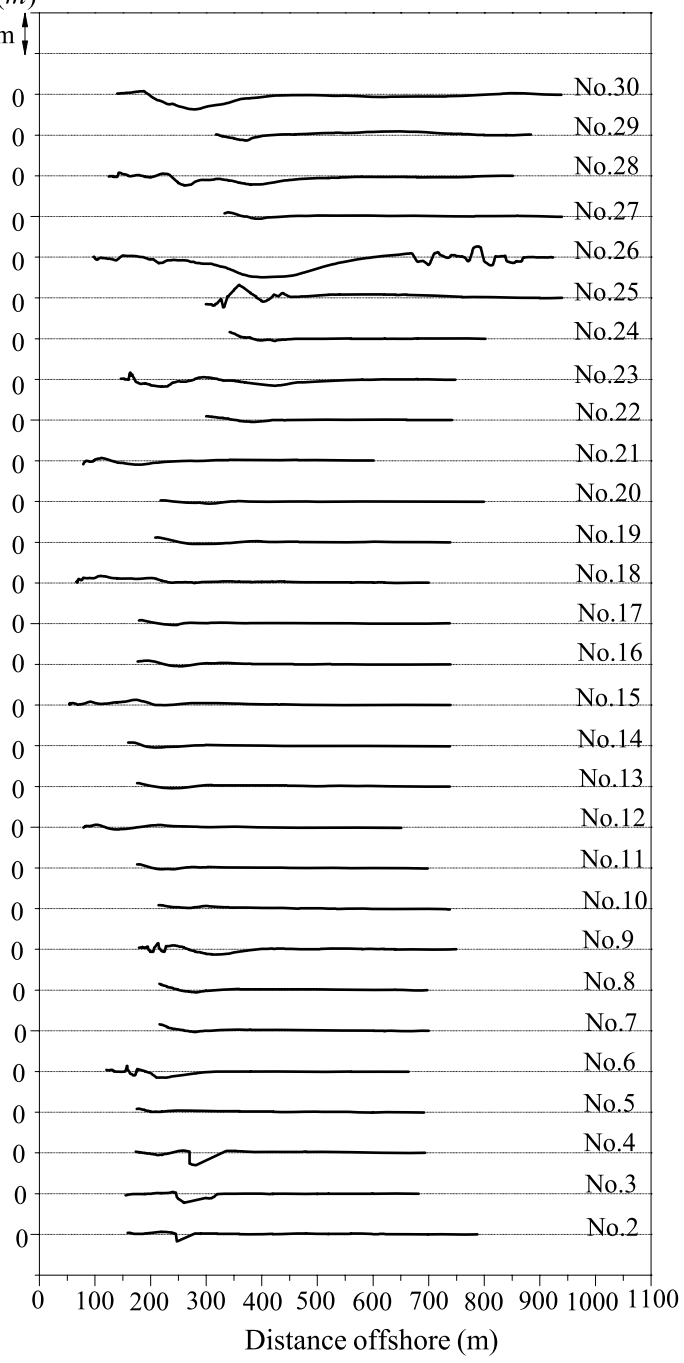

図-6 津波前後の海底高さ変化量 


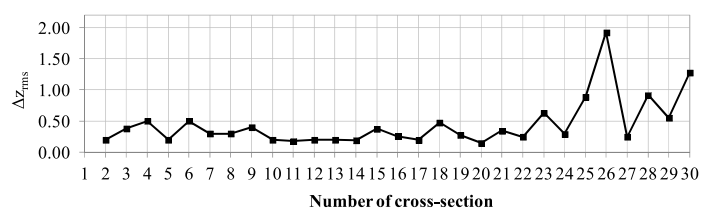

図-7 海底高さ変化量 $\Delta \mathrm{z}_{\mathrm{rms}}$

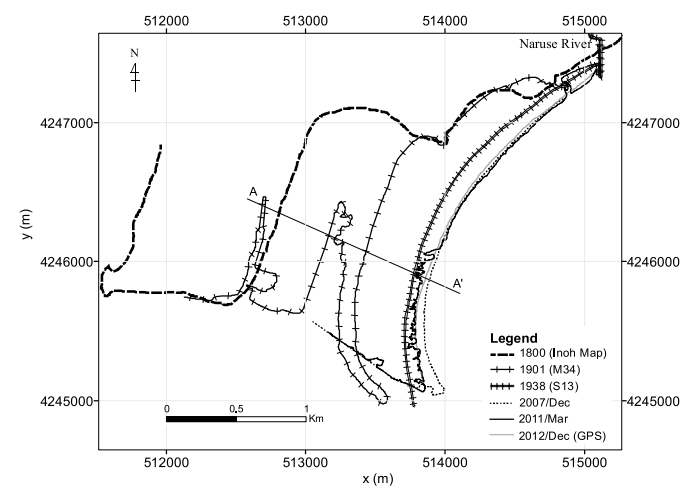

図-8 漂砂系末端での汀線変化

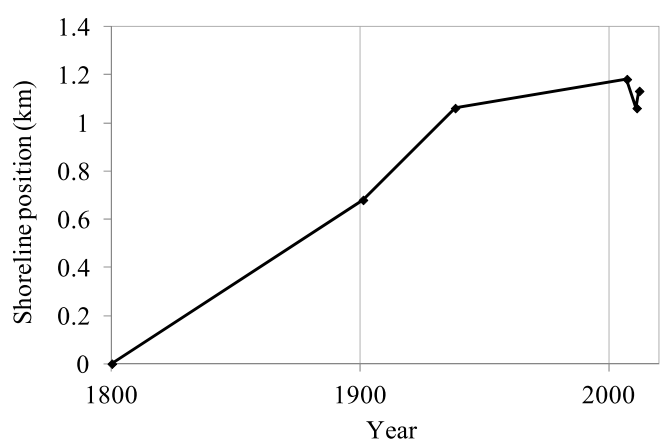

図-9＼cjkstart漂砂系末端での汀線位置の変化（A-A'）

化の二乗平均值である.

$$
\Delta z_{r m s}=\sqrt{\frac{\sum_{i=1}^{N}\left(z_{1 i-} Z_{2 i}\right)^{2}}{N}}
$$

ここで, $i$ : 岸沖方向の測点番号, $N$ : その総数である. ただし，岸沖方向については，図-6に示す区間にわたっ て式（1）による総和を求めている。すでに図-7から明 らかなように, 鳴瀬川河口より左岸側（測線 1から 24） では $\Delta z_{r m s}$ の值もきわめて小さく, 今次津波の規模に基づ く予想に反して，津波による海底面高さの変化は驚くほ ど過小である.

鳴瀬川河口部（測線 25，26）に抢いては，図-3右中段 に示したように河口前面堆積砂が大きく侵食されてお り，ここでのみ局所的に大きな $\Delta z_{r m s}$ の值を示す．鳴瀬川 河口については津波による左岸河口砂州が消滅した（田 中ら, 2011 ; Tanaka ら, 2012) が, それ以降, 河口砂州
の回復が見られない (平尾ら，2012）。この測線より右 側では漂砂系末端の測線 30 に向けて, $\Delta z_{r m s}$ 值が漸増して いる.

\section{（4）津波による汀線変化とその後の回復過程}

図-8は漂砂系末端に位置する測線 26 から 30 に至る箇所 の汀線変化である. 北側汀線の津波による変動は小さく, 上記の深浅デー夕による知見と一致している. 図-8の南 側の漂砂系端部 $1 \mathrm{~km}$ 区間のみにおいて, 最大で $140 \mathrm{~m}$ 程 度の汀線後退が生じている。

図-8に示す海浜は石巻海岸の漂砂系末端に位置するた めに, 海岸線の前進がきわめて顕著であることが知られ ている. 田中ら（2005）は, 伊能図を含む古地図や野蒜 築港の時期に作成された海図などをもとに，この 200 年 の間に $1 \mathrm{~km}$ にも及ぶことを示している.このような特性 を有する海浜において, 津波による侵食後の回復過程を 検討することはきわめて興味深い。そこで, 津波被災前 後の空中写真を入手し, 汀線変化を調べた.

図-8中の測線 A-A'における汀線位置の変化を図-9に示 している.この箇所は漂砂系の最下手に位置するため, 200 年の間で $1 \mathrm{~km}$ にもぶ大きな汀線の前進が見られて いる．漂砂系末端に位置するため，2012年12月には沿岸 漂砂による汀線の回復傾向が確認される.

\section{4. おわりに}

宮城県石巻海岸における津波前後の深浅測量データの 分析を行い，津波による海浜変形の特徵に関する検討を 行った。以下に主要な結論を示す.

（1）津波前後の深浅測量結果より，地盤沈下によるも のと考えられる海底面高さの変化が見られた. 陸上部に おいても同程度の沈下が見られることを確認した。推定 された沖合の地盤沈下量は, 陸上部で報告されている沈 下量と良い一致を示して抢り, 最大で $1.2 \mathrm{~m}$ に至る。この 值は陸上部での観測值と調和的である.

（2）地盤沈下量を差し引いた海底面高さの変化量は多 くの箇所で $20 \mathrm{~cm}$ 程度であり, 甚大な被害を及ぼした津 波の規模から予想されるものに比べてきわめて小さいも のであった。

（3）一方，河口前面の堆積地形，および漂砂系末端部 の海浜に扔いてのみ, 顕著な地形変化が見られている. その值は最大で $4.9 \mathrm{~m}$ 程度の深さである.

（4）津波で生じた侵食地形について，その後の回復過 程を空中写真・現地調查などから明らかにした。

謝辞：本研究を行うにあたり, 宮城県土木部河川課より 貴重な現地資料の提供を受けた。さらに, 本研究に対し て日本学術振興会科学研究費 (No.2301367), (財) 河川 環境管理財団河川整備基金, 東北大学災害科学国際研究 
所特定研究助成，および東北建設協会建設事業に関する 技術開発支援の助成を受けている。ここに記して関係各 位に深甚なる謝意を表する。

\section{参 考 文 献}

井上かおり・田中 仁・泉 典洋（2002）：野蒜海岸を中心と する石巻湾西部沿岸の長期土砂移動量の評価, 海岸工学 論文集，第49巻，pp.516-520.

有働恵子・田中 仁·真野 明·武田百合子：東北地方太平 洋沖地震津波による宮城県仙台湾南部海岸の海浜変形特 性, 土木学会論文集B2 (海岸工学), Vol. 69. (印刷中)

国土地理院（2011）: 平成23年（2011年）東北地方太平洋沖 地震に伴う地盤沈下調査結果について, http://www.gsi.go. jp/sokuchikijun/sokuchikijun60008.html

Nguyen Xuan Dao • Mohammad Bagus Adityawan • 田中 仁 （2013）：海岸堤防の構造に依存した津波被害と数值モデ ルによる検証, 土木学会論文集 B2 (海岸工学), Vol. 69. (印刷中)

佐藤慎司 - 山本幸次 · 和田一範 - 伊澤武二 · 大谷靖朗 ・ 橋本 新（1998）：大曲海岸におけるヘッドランド周辺の漂砂観 測と海浜地形変化予測, 海岸工学論文集, 第 45 巻, pp.556-560.

高橋智幸・首藤伸夫・今村文彦・浅井大輔（1999）：掃流砂 層・浮遊砂層間の交換砂量を考慮した津波移動床モデル の開発，海岸工学論文集，第46巻，pp.606-610.

高橋 潤 - 後藤和久 · 大家隆行 - 柳澤英明 - 今村文彦 （2008）：スリランカ・キリンダ漁港を対象とした2004年
インド洋大津波による土砂移動過程の解析, 海岸工学論 文集，第 55 巻，pp.251-255.

高橋 徽・田中 仁（2005）：石巻湾におけるへッドランド施 工による漂砂制御効果, 海岸工学論文集, 第 52 巻, pp.471475.

田中 仁・松冨英夫・泉 典洋（2005）：古地図を用いた仙台 海岸・石巻海岸の長期汀線変動に関する検討, 海岸工学論 文集, 第 52 巻, pp.556-560.

田中 仁・真野 明・有働恵子（2011）：2011年東北地方太平 洋沖地震津波による海浜地形変化, 土木学会論文集 B2（海 岸工学) , Vol. 67, No.2, pp.I_571-I_575.

原口 強・高橋智幸・久松力人・森下 祐 ・佐々木いたる (2012)：2010 年チリ中部地震津波抒よび2011 年東北地方 太平洋沖地震津波による気仙沼湾での地形変化に関する 現地調查, 土木学会論文集 B2 (海岸工学), 第 68 巻, pp.231-235.

平尾隆太郎・田中 仁・梅田 信 - Nguyen Xuan Tinh · Eko Pradjoko · 真野 明 ·有働恵子 (2012)：東日本大震災津 波後の河口地形変化の特徴と問題点, 土木学会論文集 B1 (水工学) , Vol.68, No.4, pp.I_1735-I_1740.

望月倫也 - 宇田高明 - 大類光男 - 大谷靖朗 (1990)：仙台湾北 部の海浜変形の実態, 海岸工学論文集, 第 37 巻, pp.369373.

Tanaka, H., X. T. Nguyen, M. Umeda, R. Hirao, E. Pradjoko, A. Mano and K. Udo (2012): Coastal and estuarine morphology changes induced the 2011 Great East Japan Earthquake Tsunami, Coastal Engineering Journal, Vol.54, No.1. doi: $10.1142 / \mathrm{S} 0578563412500106$ 